\title{
Integrated Management of Stem and Root Rot Disease in Sesame Caused by Macrophomina phaseolina
}

\author{
B. Meena* \\ Regional Research Station, Tamil Nadu Agricultural University, \\ Vridhachalam - 606 001, Tamil Nadu, India \\ *Corresponding author
}

\begin{tabular}{l} 
Ke y w o r d s \\
Sesame, \\
Macrophomina \\
phaseolina, \\
Trichoderma \\
asperellum, \\
Fungicides \\
\hline Article Info \\
$\begin{array}{l}\text { Accepted: } \\
\text { 26 September } 2020 \\
\text { Available Online: } \\
\text { 10 October } 2020\end{array}$ \\
\hline
\end{tabular}

\begin{abstract}
A B S T R A C T
Stem and root rot disease caused by Macrophomina phaseolina (Tassi) Goid is the destructive disease in sesame. The effect of bioagents and newer molecules of fungicides were evaluated in managing the stem and root rot disease of sesame under sick plot conditions during 2018 and 2019. Seed treatment was done with bioagent Trichoderma asperellum at the rate of $4 \mathrm{~g} / \mathrm{kg}$ of seed. Furrow application of T. asperellum (2.5 kg/ha enriched in $100 \mathrm{~kg}$ of FYM) at the rate of $250 \mathrm{~kg} / \mathrm{ha}$ was also made uniformly in all the treatments. Foliar application of fungicides was done twice one at capsule initiation stage and another at 15 days interval. From the results, it could be inferred that seed treatment with $T$. asperellum at the rate of $4 \mathrm{~g} / \mathrm{kg}$ seed; furrow application of T. asperellum $(2.5 \mathrm{~kg} / \mathrm{ha}$ enriched in $100 \mathrm{~kg}$ of FYM) at the rate of $250 \mathrm{~kg} / \mathrm{ha}$ followed by foliar application of Trifloxystrobin + Tebuconazole at the rate of $0.5 \mathrm{~g} / \mathrm{l}$ at capsule initiation and second spray after 15 days interval was highly effective in managing the stem and root rot disease of sesame as well increased the seed yield also.
\end{abstract}

\section{Introduction}

Sesame (Sesamum indicum L.), is one of the oldest oilseed crop grown widely under tropical and subtropical regions in India (Kumaraswamy et al., 2015). The low productivity has been attributed to pests and disease occurrence (Buldeo and Rane, 1978). The stem and root rot disease of Sesamum indicum caused by Macrophomina phaseolina (Tassi) Goid is the most serious one affecting the crop at the later stages of growth.
Yellowing of leaves, discolouration and rotting of roots and dark brown lesions on the stem are the prominent symptoms of root rot disease. High temperature and water stress during growing season favours the pathogen's incidence (Chattopadhyay and Kalpana Sastry, 1998). The pathogen survives in the soil for several years. The yield loss occurred up to 60 per cent due to root rot disease. The pathogen produces pycnidia which are black, flask shaped structures with an ostiole. Numerous pycnidiospores are released from 
the pycnidium. About one per cent increase in disease intensity reduces its yield by 8.36 $\mathrm{kg} / \mathrm{ha}$ (Maiti et al., 1988).

Plants contribute to the establishment of specific ecological niches of microbes in the rhizosphere by playing key role as ecosystem engineers. The microbial community at the rhizosphere reflects its functional specificity at the level of plant-microbe interactions. It suggests that taxonomically-contrasted plant growth promoting strains may coexist in soil and colonize the same rhizosphere (Asha et al., 2013). Fungicides such as carbendazim were reported to control root rot disease in various crop plants. Management of disease through fungicides alone leads to cause soil residual problem and health hazards, besides involving higher input cost. Biological control through the use of antagonistic microorganisms has recently emerged as a viable disease management strategy. Biocontrol agents work through different modes of action. This helps biocontrol agent to be more durable, more effective and without chemical residues in human food chain. The effectiveness of biocontrol agents in the management of soil-borne diseases had been reported in several crops (Meena et al., 2002; Meena et al., 2014). In addition, the bioagent, Trichoderma also acts as inducer for resistance in treated plants against certain pathogens (Harman, 2006) and can grow with wide range of temperature and other environmental conditions (Singh et al., 2010).

Biopesticides are cheaper, ecofriendly and do not pose risk of the pathogen developing resistance. Although some biological control agents may protect seeds from soil borne pathogens, they do not proliferate in the rhizoplane and rhizozphere (Papavizas, 1985). Integrating functional and ecological knowledge on microbial populations in soil will be a prerequisite in developing novel management strategies for sustainable agriculture for which the population abundance of soil microbiome is an important component.

Though root rot disease pathogen is soil borne, the secondary infection caused by pycnidia is very destructive phase in sesame leading to stem rot infection. Hence, the present research work was carried out to manage the stem and root rot disease of sesame using the bioagents, Trichoderma asperellum, Pseudomonas fluorescens and various newer molecules of fungicides.

\section{Materials and Methods}

\section{Pathogenicity studies}

Sesame (Sesamum indicum L.) plants showing typical root rot symptoms were collected and the isolation of fungus was done following the standard tissue isolation technique. Those parts of root and stem showing typical symptoms of the disease were washed in running tap water and cut into small bits. These bits were surface sterilized with 0.1 per cent mercuric chloride solutions for 30 seconds and washed thoroughly in sterile distilled water for three times to remove traces of mercuric chloride and then aseptically transferred to sterilized potato dextrose agar (PDA) plates and incubated at $27 \pm 1^{\circ} \mathrm{C}$ for three days for fungal growth. Later, the bit of fungal growth was transferred to PDA slants. The pure culture of the fungus was obtained by further growing the culture under aseptic conditions by following hyphal tip culture method (Rangaswami, 1972). After seven days of incubation, pure isolates were obtained and maintained at $4^{\circ} \mathrm{C}$ for further studies.

The pathogenic ability of $M$. phaseolina (isolated from the diseased stem) was tested in screen house on sesame. Culture of $M$. phaseolina was raised in $250 \mathrm{ml}$ Erlenmeyer 
flask containing $50 \mathrm{ml}$ of PDB (potato dextrose broth) sterilized at $15 \mathrm{lbs}$ per sq inch pressure for 20 minutes. The bits of $5 \mathrm{~mm}$ size were cut with the help of sterilized cork borer from fresh pure culture plates (5 days old) and transferred into flasks with the help of sterilized needle under aseptic conditions. After seven days of incubation in BOD incubator at $27 \pm 1{ }^{\circ} \mathrm{C}$, mycelial mats were collected and dried between folds of blotting paper for further use. Five gram of fresh mycelial mat was homogenized in blender for 2 minutes at lowest speed in $1000 \mathrm{ml}$ of sterilized water. The suspension was used to inoculate the pots containing $5 \mathrm{~kg}$ of sand: ground sesame seed mixture (9:1) which was sterilized by autoclaving at 15 psi for one and half hours for two consecutive days. On the third day of inoculation, thirty seeds of sesame were sown in pots. Pots were irrigated regularly to maintain moisture. After 8-10 days of sowing, the symptoms appeared and the infected plants exhibited elongated lesions at collar region which will be later converted to dark brown to black and stem was completely girdled by the lesions. The affected plants wilted and dried up later. Diseased plants were brought to laboratory and isolations were made on PDA medium from diseased stem to confirm the identity of pathogen (Riker and Riker, 1936).

Field studies on the management of stem and root rot of sesame using bioagents and fungicides

Field eperiment was conducted in the New Farm, Regional Research Station, Vridhachalam during kharif 2018 and kharif 2019 to study the effect of bioagent viz., Trichoderma asperellum and fungicides for the management of stem and root rot disease of sesame under sick plot conditions. The field experiment was conducted in a plot size of $2.4 \times 3.0 \mathrm{~m}$ with eight treatments and three replications in $\mathrm{RBD}$ using the susceptible variety VRI-1 for the management of stem and root rot disease of sesame.

The seeds of sesame were treated with $T$. asperellum talc based formulation at $4 \mathrm{~g}$ per $\mathrm{kg}$ of seed before sowing. Furrow application of $T$. asperellum $(2.5 \mathrm{~kg} / \mathrm{ha}$ enriched in 100 $\mathrm{kg}$ of FYM) @ $250 \mathrm{~kg} / \mathrm{ha}$ was also made uniformly in all the treatments. Seed treatment (ST) with $T$. asperellum at the rate of $4 \mathrm{~g} / \mathrm{kg}$ seed and furrow application of $T$. asperellum $(2.5 \mathrm{~kg} / \mathrm{ha}$ enriched in $100 \mathrm{~kg}$ of FYM) at the rate of $250 \mathrm{~kg} / \mathrm{ha}$ was common for treatments $T_{1}-T_{7}$. Spraying of bioagent, Pseudomonas fluorescens was done at the rate of $5 \mathrm{~g} / \mathrm{l}$ twice one at capsule initiation and second spray after 15 days interval. Fungicides viz., Trifloxystrobin + Tebuconazole @ 0.5 g/l; Azoxystrobin @ 1.0 ml/l; Pyraclostrobin + Metiram @ 3.0 g/l; Cymoxanil + Mancozeb @ 2.0 g/l; Captan + Hexaconazole @ $2.0 \mathrm{~g} / \mathrm{l}$ and Carbendazim + Mancozeb@2.5 g/l were sprayed at capsule initiation and second spray after 15 days interval. Seeds not treated with bioagent or sprayed with fungicides will be served as the control.

The root rot disease incidence was recorded at the time of physiological maturity (90 days after sowing) by counting the number of infected plants and total number of plants. Seed yield was also recorded for each treatment and the data were statistically analyzed.

Per cent disease incidence was calculated using the formula

Number of infected plants

Disease Incidence $(\%)=---------------$ x 100

Total number of plants

\section{Results and Discussion}

In the field trial conducted for the management of root rot disease of sesame 
during kharif 2018, all the treatments were found to be superior over control. Among the treatments, seed treatment with $T$. asperellum at the rate of $4 \mathrm{~g} / \mathrm{kg}$ seed; furrow application of $T$. asperellum $(2.5 \mathrm{~kg} / \mathrm{ha}$ enriched in 100 $\mathrm{kg}$ of FYM) at the rate of $250 \mathrm{~kg} / \mathrm{ha}$ followed by foliar application of Trifloxystrobin + Tebuconazole at the rate of $0.5 \mathrm{~g} / \mathrm{l}$ at capsule initiation and second spray after 15 days interval recorded the lowest disease incidence of $24.6 \%$ (Table 1). This was found to be on par with foliar spraying of Azoxystrobin at the rate of $1.0 \mathrm{ml} / \mathrm{l}$ at capsule initiation and second spray after 15 days interval which recorded the disease incidence of $28.3 \%$. The maximum disease incidence of $56.4 \%$ was observed in the control (Table 1). Pastrana et al. (2016) reported that Asperellum was the most effective in reduction of crown and root rot caused by Fusarium solani (up to $100 \%$ in greenhouse and $81 \%$ under field conditions). Fiki and Farouk (2017) reported maximum inhibition of soil borne pathogens viz., Rhizoctonia solani, Fusarium solani, $F$. oxysporum and $M$. phaseolina by $T$. harzianum. The fungicide propiconazole was the most effective fungicide in controlling fruit rot of pomegranate caused by Alternaria alternata as reported by Singh and Majumdar (2002). Gohel and Solanky (2011) documented that maximum disease control of chilli leaf spot caused by Alternaria alternata was observed under field conditions.

Table.1 Effect of fungicides and bioagents for the management of stem and root rot disease of sesame caused by Macrophomina phaseolina (kharif 2018)

\begin{tabular}{|c|c|c|c|}
\hline S.No & Treatments & $\begin{array}{l}\text { Root rot } \\
(\%)\end{array}$ & $\begin{array}{c}\text { Yield } \\
\text { (kg/ha) }\end{array}$ \\
\hline $\mathbf{T}_{1}$ & $\begin{array}{l}\text { Spraying of Pseudomonas fluorescens @ } 5 \mathrm{~g} / 1 \text { at capsule } \\
\text { initiation and second spray after } 15 \text { days interval }\end{array}$ & $\begin{array}{c}44.8 \\
(42.3)\end{array}$ & 496 \\
\hline $\mathbf{T}_{2}$ & $\begin{array}{l}\text { Spraying of Trifloxystrobin + Tebuconazole @ } 0.5 \mathrm{~g} / \mathrm{l} \text { at } \\
\text { capsule initiation and second spray after } 15 \text { days interval }\end{array}$ & $\begin{array}{l}24.6 \\
(26.4)\end{array}$ & 624 \\
\hline $\mathbf{T}_{3}$ & $\begin{array}{l}\text { Spraying of Azoxystrobin @ } 1.0 \mathrm{ml} / 1 \text { at capsule initiation and } \\
\text { second spray after } 15 \text { days interval }\end{array}$ & $\begin{array}{c}28.3 \\
(27.5)\end{array}$ & 616 \\
\hline $\mathbf{T}_{4}$ & $\begin{array}{l}\text { Spraying of Pyraclostrobin + Metiram @ } 3.0 \mathrm{~g} / \mathrm{l} \text { at capsule } \\
\text { initiation and second spray after } 15 \text { days interval }\end{array}$ & $\begin{array}{c}33.4 \\
(31.7)\end{array}$ & 587 \\
\hline $\mathbf{T}_{5}$ & $\begin{array}{l}\text { Spraying of Cymoxanil + Mancozeb @ } 2.0 \mathrm{~g} / 1 \text { at capsule } \\
\text { initiation and second spray after } 15 \text { days interval }\end{array}$ & $\begin{array}{c}30.7 \\
(28.3)\end{array}$ & 596 \\
\hline$T_{6}$ & $\begin{array}{l}\text { Spraying of Captan + Hexaconazole @ } 2.0 \mathrm{~g} / 1 \text { at capsule } \\
\text { initiation and second spray after } 15 \text { days interval }\end{array}$ & $\begin{array}{c}35.1 \\
(32.6)\end{array}$ & 563 \\
\hline $\mathbf{T}_{7}$ & $\begin{array}{l}\text { Spraying of Carbendazim + Mancozeb @ } 2.5 \mathrm{~g} / \mathrm{l} \text { at capsule } \\
\text { initiation and second spray after } 15 \text { days interval }\end{array}$ & $\begin{array}{c}39.5 \\
(37.1)\end{array}$ & 528 \\
\hline $\mathbf{T}_{8}$ & Untreated check & $\begin{array}{c}56.4 \\
(53.9)\end{array}$ & 424 \\
\hline \multicolumn{2}{|r|}{ SEd } & 3.53 & 16.4 \\
\hline \multicolumn{2}{|r|}{$\mathrm{CD}(\mathrm{P}=0.05)$} & 7.91 & 34.9 \\
\hline
\end{tabular}

*Mean of three replications

Note: Seed treatment (ST) with T. asperellum @ $4 \mathrm{~g} / \mathrm{kg}$ + furrow application of enriched in $100 \mathrm{~kg}$ of FYM) @ $250 \mathrm{~kg} / \mathrm{ha}$ is common for $\mathrm{T}_{1}-\mathrm{T}_{7}$. 
Table.2 Effect of fungicides and bioagents for the management of stem and root rot disease of sesame caused by Macrophomina phaseolina (kharif 2019)

\begin{tabular}{|c|c|c|c|}
\hline S.No & Treatments & $\begin{array}{c}\text { Root rot } \\
(\%)\end{array}$ & $\begin{array}{c}\text { Yield } \\
(\mathrm{kg} / \mathrm{ha})\end{array}$ \\
\hline $\mathbf{T}_{1}$ & $\begin{array}{l}\text { Spraying of Pseudomonas fluorescens @ } 5 \mathrm{~g} / 1 \text { at capsule } \\
\text { initiation and second spray after } 15 \text { days interval }\end{array}$ & $\begin{array}{c}39.7 \\
(39.0)\end{array}$ & 463 \\
\hline $\mathbf{T}_{2}$ & $\begin{array}{l}\text { Spraying of Trifloxystrobin + Tebuconazole @ } 0.5 \mathrm{~g} / \mathrm{l} \text { at } \\
\text { capsule initiation and second spray after } 15 \text { days interval }\end{array}$ & $\begin{array}{c}22.4 \\
(28.1)\end{array}$ & 618 \\
\hline $\mathbf{T}_{3}$ & $\begin{array}{l}\text { Spraying of Azoxystrobin @ } 1.0 \mathrm{ml} / \mathrm{l} \text { at capsule initiation and } \\
\text { second spray after } 15 \text { days interval }\end{array}$ & $\begin{array}{c}27.1 \\
(31.3)\end{array}$ & 583 \\
\hline $\mathbf{T}_{4}$ & $\begin{array}{l}\text { Spraying of Pyraclostrobin + Metiram @ } 3.0 \mathrm{~g} / \mathrm{l} \text { at capsule } \\
\text { initiation and second spray after } 15 \text { days interval }\end{array}$ & $\begin{array}{c}32.7 \\
(34.8)\end{array}$ & 556 \\
\hline $\mathbf{T}_{5}$ & $\begin{array}{l}\text { Spraying of Cymoxanil + Mancozeb @ } 2.0 \mathrm{~g} / \mathrm{l} \text { at capsule } \\
\text { initiation and second spray after } 15 \text { days interval }\end{array}$ & $\begin{array}{c}30.6 \\
(33.5)\end{array}$ & 567 \\
\hline $\mathbf{T}_{6}$ & $\begin{array}{l}\text { Spraying of Captan + Hexaconazole @ } 2.0 \mathrm{~g} / 1 \text { at capsule } \\
\text { initiation and second spray after } 15 \text { days interval }\end{array}$ & $\begin{array}{c}34.9 \\
(36.2)\end{array}$ & 524 \\
\hline $\mathbf{T}_{7}$ & $\begin{array}{l}\text { Spraying of Carbendazim + Mancozeb @ } 2.5 \mathrm{~g} / \mathrm{l} \text { at capsule } \\
\text { initiation and second spray after } 15 \text { days interval }\end{array}$ & $\begin{array}{c}37.3 \\
(37.6)\end{array}$ & 496 \\
\hline $\mathbf{T}_{8}$ & Untreated check & $\begin{array}{c}48.9 \\
(44.4)\end{array}$ & 428 \\
\hline & SEd & 2.57 & 21.78 \\
\hline \multicolumn{2}{|r|}{$\mathrm{CD}(\mathrm{P}=\mathbf{0 . 0 5})$} & 5.58 & 42.31 \\
\hline
\end{tabular}

*Mean of three replications

Note: Seed treatment (ST) with T. asperellum @ $4 \mathrm{~g} / \mathrm{kg}+$ furrow application of enriched in $100 \mathrm{~kg}$ of FYM) @ $250 \mathrm{~kg} / \mathrm{ha}$ is common for $\mathrm{T}_{1}-\mathrm{T}_{7}$.

Pethybridge et al. (2007) highlighted that berries from the cyprodinil+fludioxonil treatment had the lowest incidence of Botrytis fruit rot of strawberry incited by Botrytis cinerea. Spraying of Pseudomonas fluorescens@5 g/l at capsule initiation and second spray after 15 days interval was not effective in managing the root rot disease which recorded $44.8 \%$ disease incidence (Table 1).

In addition to disease reduction, the maximum seed yield of $624 \mathrm{~kg} / \mathrm{ha}$ was observed in the effective treatment of seed treatment with $T$. asperellum at the rate of $4 \mathrm{~g} / \mathrm{kg}$; furrow application of $T$. asperellum $(2.5 \mathrm{~kg} / \mathrm{ha}$ enriched in $100 \mathrm{~kg}$ of FYM) at the rate of 250 $\mathrm{kg} / \mathrm{ha}$ followed by foliar application of
Trifloxystrobin + Tebuconazole at the rate of $0.5 \mathrm{~g} / \mathrm{l}$ at capsule initiation and second spray after 15 days interval (Table 1). The population dynamics and functional richness of rhizosphere ecosystem in black pepper influenced by the treatment with $T$. harzianum provides the ecological importance of $T$. harzianum in the cultivation of black pepper (Umadevi et al., 2018). This was followed by spraying of Azoxystrobin @ $1.0 \mathrm{ml} / \mathrm{l}$ at capsule initiation and second spray after 15 days interval with the seed yield of $616 \mathrm{~kg} / \mathrm{ha}$ (Table 1). Spraying of Pseudomonas fluorescens@5 g/l at capsule initiation and second spray after 15 days interval recorded the seed yield of $496 \mathrm{~kg} / \mathrm{ha}$. The minimum seed yield of $424 \mathrm{~kg} / \mathrm{ha}$ was observed in the control (Table 1). Anandaraj and Sarma 
(2003) reported that the application of $T$. harzianum (MTCC 5179) resulted in enhanced growth in black pepper with increased number of nodes, and consequently the number of cuttings. Treatment with $T$. harzianum (MTCC 5179) individually imparted better growth promotion and disease suppression than that of a consortia of plant growth-promoting rhizobacteria alone or in combination with $T$. harzianum (MTCC 5179) (Sibi, 2013). These studies indicated growth promotion and the organism was recommended as a component of integrated disease management and without a clear understanding of other mechanisms.

In the field trial conducted during kharif 2019 for the management of stem and root rot disease of sesame, all the treatments were found to be superior over control. Among the treatments, seed treatment with T.viride@10 $\mathrm{g} / \mathrm{kg}+$ furrow application of $T$. viride $(2.5$ $\mathrm{kg} / \mathrm{ha}$ enriched in $100 \mathrm{~kg}$ of FYM) @ 250 $\mathrm{kg} / \mathrm{ha}+$ foliar spray of Trifloxystrobin + Tebuconazole@0.5 g/l at capsule initiation and second spray after 15 days interval recorded the minimum disease incidence $(22.4 \%)$ and the maximum yield of $618 \mathrm{~kg} / \mathrm{ha}$ (Table 2). This was found to be on par with foliar spraying of Azoxystrobin @ $1.0 \mathrm{ml} / \mathrm{l}$ at capsule initiation and second spray after 15 days interval which recorded the disease incidence $(27.1 \%)$ and the yield of $583 \mathrm{~kg} / \mathrm{ha}$. The maximum disease incidence of $48.9 \%$ and the minimum yield of $428 \mathrm{~kg} / \mathrm{ha}$ was observed in the control (Table 2).

From the present study, it could be concluded that stem and root rot disease of sesame can be managed effectively using the integration of bioagent, $T$. asperellum (seed treatment and furrow application) and foliar application of fungicides (Trifloxystrobin + Tebuconazole@0.5 g/l at capsule initiation and second spray after 15 days interval).

\section{Acknowledgements}

The financial support rendered by ICAR-All India Co-ordinated Research Project on Sesame \& Niger in carrying out this research work is gratefully acknowledged.

\section{References}

Anandaraj, M.and Sarma, Y.R. 2003. The potential of PGPR in disease management of Spice crop. Proceedings of the $6^{\text {th }}$ International PGPR Workshop, Calicut, India; pp.27-39.

Asha, N.N., Raghunandan, B.L. and Shivaprakash, M.K. 2013. In vivo evaluation of Trichoderma spp. for survival and their population in rhizosphere soil from french bean. Madras Agric. J., 100: 554-558.

Buldeo, A.M. and Rane, M.S. 1978. Fusarium wilt of sesamum. J. Maharashtra Agric. Univ., 3: 167-170.

Chattopadhyay, C. and Kalpana Sastry, R. 1998. Important diseases of sesame and their management options. In: IPM systems in Agriculture, (Oilseeds), RK Upadhyay, KG Mukerjie, RL Rajak (eds.), Oxford and IBH Publ., New Delhi.

Fiki, I. and Farouk, M. 2017. Effect of biological control of root rot diseases of strawberry using Trichoderma spp. Research Journal of Applied Sciences, 7: 482-492.

Gohel, N.M. and Solanky, K.U. 2011. In-vitro and in-vivo evaluation of fungicies against Alternaria alternata causing leaf spot and fruit rot disease of chilli. Green Farming, 3: 84-86.

Harman, G.E. 2006. Overview of mechanisms and uses of Trichoderma spp. Phytopathology, 96: 190-194.

Kumaraswamy, H.H., Jawaharlal, J., Ranganatha, A.R.G. and Chander Rao, S. 2015 Safe sesame (Sesamum indicum 
L.) production: Perspectives, practices and challenges. Journal of Oilseeds Research, 32: 1-24.

Maiti, S., Hegde, M.R. and Chattopadhyay, S.B. 1988. Handbook of Annual Oilseed Crops. Oxford and IBH Publ. Co. Pvt. Ltd., New Delhi,

Meena, B., Radhajeyalakshmi, R., Marimuthu, T., Vidhyasekaran, P. and Velazhahan, R. 2002. Biological control of groundnut late leaf spot and rust by seed and foliar applications of a powder formulation of Pseudomonas fluorescens. Biocontrol Sci. Technol., 12: 195-204.

Meena, B., Ramjegathesh, R. and Ramyabharathi, S.A. 2014. Evaluation of bio-control agents and fungicides against the stem bleeding disease of coconut. Journal of Plantation Crops, 42: $1-5$.

Papavizas, G.C. 1985. Trichoderma and Gliocladium: Biology, ecology and potential for biocontrol. Annu. Rev. Phytopathol., 23: 23-54.

Pastrana, A.M., Ureba, M.J.B., Aguado, A., Akdi, K. and Capote, N. 2016. Biological control of strawberry soilborne pathogens Macrophomina phaseolina and Fusarium solani, using Trichoderma asperellum and Bacillus spp. Phytopathologia Mediterranea, 55: 109-120.

Pethybridge, S.J., Hay, F.S., Wilson, C.R. and Groom, T. 2007. Development of a fungicide-based management strategy for foliar disease caused by Phoma ligulicola in Tasmanian Pyrethrum fields. APS Publications, 89: 1114.

Rangaswami, G. 1972. Diseases of crop plants in India. Prentice Hall of India Pvt. Ltd. New Delhi, p.520.

Riker, A.J. and Riker, A.S. 1936. Introduction to research on plant diseases. John. S. Swift, C.M.C., New York, 117p.

Sibi, M.C. 2013. The potential of PGPR in disease management of Spice crop. Proceedings of the 6th International PGPR Workshop, Calicut, India, pp.2739.

Singh, J. and Majumdar, V.L. 2002. Fungicidal management of Alternaria rot in pomegranate. J. Mycol. Pl. Path., 32: 134.

Singh, V., Singh, P.N., Yadav, R.L., Awasthi, S.K., Singh, R.K. and Duttamajumder, S.K. 2010. Increasing the efficiency of Trihoderma harzianum for nutrient uptake and control of red rot in sugarcane. $J$. of Horticulture and Forestry, 2: 66-71.

Umadevi, P., Anandaraj, M., Srivastav, V. and Benjamin, S. 2018. Trichoderma harzianum MTCC 5179 impacts the population and functional dynamics of microbial community in the rhizosphere of black pepper (Piper nigrum L.). Brazilian Journal of Microbiology, 49: 463-470.

\section{How to cite this article:}

Meena, B. 2020. Integrated Management of Stem and Root Rot Disease in Sesame Caused by Macrophomina phaseolina. Int.J.Curr.Microbiol.App.Sci. 9(10): 3764-3770.

doi: https://doi.org/10.20546/ijcmas.2020.910.433 